\title{
Race and treating other people's children as adults
}

\author{
Rodger Jackson ${ }^{\mathrm{a}}$, Edward Pabon ${ }^{\mathrm{b}, *}$ \\ ${ }^{\mathrm{a}}$ Richard Stockton College of New Jersey, Pomona, NJ, USA \\ ${ }^{\mathrm{b}}$ School of Social Work, Marywood University, 2300 Adams Avenue, Scranton, PA 18509, USA
}

\begin{abstract}
Juvenile offenders are sometimes transferred to a criminal court where they may stand trial as adults. The rationale for this current trend cannot be justified based on evidence from developmental psychology, the evidence of consistent positive effects for particular intervention strategies, and ethical arguments for justification of punishment. The rationale in actuality reflects the selective manipulation of the alternative conceptions of young people as dependent and vulnerable or as autonomous and responsible to continue to justify policies that entail cultural and racial discrimination. Discretionary decisions at various stages of the justice process amplify racial disparities as minority youths proceed through the system and result in more severe dispositions than for comparable White youths. (C) 2000 Elsevier Science Ltd. All rights reserved.
\end{abstract}

\section{Introduction}

Juvenile offenders are sometimes transferred to a criminal court where they may stand trial as adults. Various mechanisms are used to affect these transfers. Some states automatically exclude certain cases from juvenile courts; others give prosecutors authority to file specific cases directly in criminal court. In some states, juvenile court judges may transfer certain cases by "waiving" the juvenile court's original jurisdiction.

A desire to "get tough" as a result of the growing fear of juvenile crime has provided an opportunity to increase the number of young offenders transferred to criminal courts for prosecution as adults. Between 1987 and 1994, the number of cases transferred annually to criminal court via judicial waiver rose by 73 percent, from 6800 to 11700 (Stahl, 1999). The number of waived cases declined by 17 percent in 1995 and then increased by 2 percent in 1996 . Over

* Corresponding author. Tel.: +1-570-348-6282; fax: $+1-570-961-4742$.

E-mail address: pabon@ac.marywood.edu (E. Pabon). the same time frame, while the juvenile violent crime arrest rate increased by more than 60 percent from 1987 to 1994, it declined by 23 percent from 1994 to 1997 (Snyder, 1998). In spite of the decline, the proportion of juvenile arrests sent directly to the criminal court in 1997 (7 percent) was the highest in the last two decades.

The rationale for this current trend cannot be justified based on evidence from developmental psychology, the evidence of consistent positive effects for particular intervention strategies, and ethical arguments for justification of punishment. The rationale in actuality reflects the selective manipulation of the alternative conceptions of young people as dependent and vulnerable or as autonomous and responsible to continue to justify policies that entail cultural and racial discrimination. Discretionary decisions at various stages of the justice process amplify racial disparities as minority youths proceed through the system and result in more severe dispositions than for comparable White youths.

The current convergence between juvenile and criminal justice systems reflects a continuation of a long-term tradition of imposing punitive policies and 
sanctions on "other people's children," especially minority youths (Feld, 1998). Sixty-three percent of all juvenile offenders in residential placement in 1997 were minorities (Gallagher, 1999).

Current transfer policy signals a continued undermining of the principles of juvenile justice for minority offenders, and a return to vengeance highlighting an increase in the fear of "other people's children" resulting as much from cumulative political, historical, and racial forces as from purposeful design. The waiver of juvenile offenders to the adult system and the imposition of harsher punishment in the juvenile justice system constitutes a continual tendency to distinguish between "our children" and "other people's children" (Feld, 1998; Zimring, 1998).

\section{The changing perspective of juvenile justice?}

Around the end of the nineteenth century, social structural changes associated with modernization sparked the Progressive movement (Hofstader, 1955). Progressivism encompassed a host of ideologies and addressed a broad spectrum of issues: economic regulation criminal justice, social welfare, education, etc.) Social welfare historians usually argue that the creation at the turn of the century of a separate system of juvenile justice reflected the understanding of the nature of crime and a new recognition of psychological differences between youths and adults, which was emerging from the "new" science of psychology (Ryerson, 1977).

Under the rehabilitative model of juvenile justice, policy makers assumed that juvenile offenders have different capacities and needs from adults that warranted separate adjudication procedures and a differential correctional response. The reformers also believed that the criminal acts of youthful offenders reflected their immaturity; thus, juveniles were not criminally responsible and should not be subject to the same punishment as adults. Neither the retributive nor deterrent purposes of the criminal law were appropriately served with this group.

In the post-Gault period, policy makers grappled with the challenge of constructing a retributive system that held juveniles responsible for criminal acts, but still recognized the youth and immaturity of juvenile offenders (Scott \& Grisso, 1997). The criminal choices of juveniles were seen as less culpable and thus as deserving less punishment than were those of adults. Statutory policies generally reflected the reformers' core prescription-limiting retribution - which most juveniles, because of developmental immaturity, should be subject to less punishment than adult criminals.
The constraint on retribution that weighed so heavily with the post-Gault reformers has become considerably less important in recent years. The emphasis today is on social control, on protecting society from the harms inflicted by young offenders, and the clear trend has been toward imposing penalties that approximate sanctions imposed on adults. Critics of the social control approach argue that this approach to juvenile criminal conduct differs from the earlier progressive and post-Gault policies. Current policies rests on an assumption of adolescent competence, implicitly holding that there are no psychological differences between adolescent and adult offenders that are important to criminal responsibility or to participation in an adult criminal proceeding. Those who would treat young offenders as adults appear to assume that almost all juveniles meet any standard for maturity that might be relevant.

Yet, while this social control approach might differ in its assumption of adolescent competence, it is very much in keeping with the overall direction of juvenile justice policies developed in the late nineteenth century. From the beginning, progressive and post-Gault reformers intended and designed the juvenile justice system to discriminate between middleclass children like their own and those of poor White and minority parents (Schlossman, 1977; Rothman, 1980). Juvenile justice sentencing practices constituted a form of "criminological triage" based on social and racial circumstances (Feld, 1998). This strategy selectively manipulates the alternative conceptions of young people as dependent and vulnerable or as autonomous and responsible to continue to justify policies that entail social, economic, cultural, and racial discrimination. It removes many middleclass, White juvenile offenders from the juvenile justice system to the private social service systems. It imposes increasingly harsher punishment on those middle range juveniles who remain within the juvenile court system. In addition, it justifies the disproportionate consignment of minority youth to criminal court for prosecution as adults.

From the inception of juvenile courts, their judges could deny some young offenders the court's protective jurisdiction and transfer their cases to adult criminal courts. From the beginning, "the judges responded to children like their own with 'tenderness' - supervising them on probation - and reacted to the 'foreign' and 'alien' youth with 'toughness' routing them to the institutions" (Schlossman, 1977). This "criminological triage" provided a powerful and legitimating policy for the disproportionate punitive handling of poor White and minority offenders. Minority youth usually outnumber nonminority White youth in public custody facilities by more than 2 to 1 (Sickmund et al., 1997). 


\section{Perspective on adolescence}

Current developmental psychology offers a useful perspective from which to examine and evaluate the changing conceptions of adolescence that have been reflected in the current legal responses to juvenile crime.

Particular developmental influences on individual decision making shape the choices of youthful actors in ways that distinguishes them from adults. Most familiar are elements of cognitive development reasoning and understanding. More salient to decisions about participation in criminal conduct are psychosocial factors such as (1) conformity and compliance in relation to peers (Rogers, 1981), (2) attitude toward and perception of risk (Elkind, 1967), and (3) temporal perspective (Steinberg \& Cauffman, 1996). These psychosocial factors affect decision making in powerful ways that may distinguish juveniles from adults. The impact is not on cognitive competence, narrowly defined, but rather on "judgment" (as the term is used in common parlance). The traditional presumption (in juvenile justice and in many other policy areas) that minors are not fully accountable and need legal protection rests in part on a view that their judgment is immature. In essence, the intuition is that developmentally linked predispositions and responses systematically affect decision making of adolescents in ways that may incline them to make choices that threaten harm to them and to others. Whereas, cognitive competence affects the process of decision making, immature judgment is reflected in outcomes, in that developmental factors influence values and preferences, which in turn shape the cost-benefit calculus.

It is generally recognized that decision-making capacities increase through childhood into adolescence and that, although there is great variability among individuals, preadolescents and younger teens differ substantially from adults in their abilities. Development occurs along several lines. The capacities to process information and to think hypothetically develop into adolescence, and cognitive performance improves generally due to knowledge gained in specific domains. Moreover, cognitive skills acquired earlier mature and develop into adolescence (Kietzman et al., 1985).

The scientific research supports the claim that adolescents are more competent decision makers than has been presumed under paternalistic policies. The evidence for the claim that their cognitive decision making capacity is comparable to that of adults is unclear. Studies that support the claim of competence are small and most involve middle class subjects of average intelligence. Only a handful compares the decision making of minors with that of adults. Most studies of adolescent decision making have been conducted in laboratory settings in which the decision is hypothetical and "pre-framed" in the sense that all relevant information is provided to the subjects. This format yields little useful data about how decisions are made in informal unstructured settings (such as the street), in which decision makers must rely on their own experience and knowledge in making choices.

Developmental influences relating to understanding and judgment affect adolescent choices to commit crime in ways that distinguish most young offenders from their adult counterparts. Although individual adult and juvenile offenders may vary, decisionmaking factors associated with age that affects decision making provide a basis for differentiating between the two categories of offenders. Thus, the current trend of transferring youth to the criminal court and the concept of adolescence offered by the modern punitive reformers cannot be justified based on the evidence from developmental psychology.

\section{Skepticism as to rehabilitation}

Implicit in the recent reforms is the assumption that, even if developmental differences do distinguish adolescent and adult offenders, the enormous social costs inflicted by young criminals requires that those differences be ignored in formulating a legal response to youth crime because of the skepticism about the potential and effectiveness of rehabilitation.

Rehabilitation refers to the process of attempting to change the propensity of individual offenders to commit crimes through training, education, and other services. The rehabilitative role of juvenile correctional programs was set back considerably by a series of scholarly reviews of the evaluative literature in the late 1970s, which were interpreted as saying that "nothing worked" or, more precisely, that there was insufficient evidence to conclude that treatment worked or that any one particular method of treatment was more effective than any other (Martinson, 1974).

A number of critics responded to the generally defeatist tone of the "nothing works" reviews by pointing out that each of the reviews contained numerous references to programs that did work and that a more rigorous screening on therapeutic integrity and program quality could identify programs that were effective. When reviewers began using the new technique of meta-analysis, systematic reviews of the evaluation literature began turning up evidence of consistent positive effects for particular intervention strategies.

The most recent review confirms the conclusions of past meta-analysis studies (Garrett, 1985; Lipsey, 
1992; Palmer, 1992). Lipsey and Wilson (1998) reviewed 200 experimental and quasi-experimental studies that investigated the effectiveness of various interventions for reducing the recidivism of serious juvenile offenders. Two broad categories of intervention were examined: (a) programs and treatments for serious juvenile offenders who were in the community; and (b) programs and treatments for institutionalized juvenile offenders. Reductions in the area of 40 percent for recidivism were found in community programs that offered interpersonal skill training, behavioral approaches, and drug abstinence services. For institutional programs, large recidivism reduction effects were found for interpersonal skills training, cognitive-behavioral programs, and teaching family home services.

In summary, recent meta-analysis studies challenge the defeatist tone of the "nothing works" supporters and endorse the notion that there is evidence of consistent positive effects for particular intervention strategies.

If evidence from developmental psychology challenges the account of adolescence offered by the modern punitive reformers, and meta-analysis studies indicate that there is evidence of consistent positive effects for particular intervention strategies, then one must depend on an ethical justification of punishment to support the current trend in transfer policy. Even here, one is left with unreasonable assumptions.

\section{Utilitarian and retributive justifications of punishment}

\begin{abstract}
Criminal punishment is coercive state power in its most brutal form. It is a legal mechanism that allows us to take some of our fellow citizens and lock them in cages — or even kill them. Actually imposing such hard treatment on people typically curtails their liberty, stigmatizes and humiliates them, and makes them suffer. . (Murphy, 1995).
\end{abstract}

By increasing the transfer of juveniles to the adult system society is, in effect, abandoning the traditional approach to treating juveniles and punishing juveniles by the same standards as it does presently with adult offenders. It needs to be known whether there is an adequate ethical justification for this change in policy or else these changes are nothing more than an illegitimate attempt by legislators and members of the criminal justice system to assuage our contemporary fears about juvenile crime. After all, if the law is to be more than simply a codified version of mob vengeance, it requires a moral foundation.

There are primarily three approaches to justifying punishments. First, there are those approaches that purport to show that the harsh treatment inflicted on criminals, while it might be wrong under other circumstances, is not wrong as punishment. Retributivist arguments of the sort given by Kant (1979) tend to fall into this category. Second, there are those approaches that maintain punishment is inherently evil, but is necessary to protect the community by deterring or incapacitating offenders. The defenders of such views, people such as Mill (1983), tend to be utilitarians. Third, there are those like Ten (1987), who try to maintain both strains either by advocating pluralism or a blending of the two approaches.

In most criminal justice textbooks, the section on punishment presents the reader with five different "goals" of punishment, three of which are: general deterrence, specific deterrence, and incapacitation. Punishment is seen as a possible method of achieving one of these effects. In the ensuing discussion about the empirical evidence for and against these goals, it is sometimes forgotten that they are simply that, goals, and not justifications. To claim that locking a juvenile in with adults for twenty-five years prevents the offender from committing any future crimes by incapacitating him may or may not be true, but this claim does not constitute adequate ethical justification for the action. It is equally true that executing people who double park their car will prevent further future crimes by them, but, presumably, such an action would not be ethically justified.

When more closely examined, the primary moral justification for the goals of deterrence and incapacitation is some version of utilitarianism. The utilitarian assessment of punishment depends upon examining a range of possible actions, considering all the affected parties, and determining which one among this set is the best at maximizing the overall utility. If it turns out that a form of punishment, such as jail, a fine, or even death, will accomplish this, then the utilitarian is justified in punishing the offender. If there is an action that will not punish the offender and yet will increase overall utility, that is the ethically correct action to take.

It is against this background that the goals of general deterrence, specific deterrence, and incapacitation are morally justified and it is against this background that the policy of transferring juveniles needs to be evaluated. A policy that manages to effectively make individuals refrain from committing crimes increases the overall happiness of everyone affected. The relationship between all these elements and how a utilitarian argument for the policy of juvenile transfers would be structured can now be better understood:

- Policy makers are obligated to maximize overall utility. 
- Reducing crime will do this.

- Policies that deter or incapacitate individuals are the best way to reduce crime, even though they cause unhappiness to those who are being punished.

- Treating juvenile offenders as adults either deters or incapacitates them.

As a result, one can be ethically justified in treating juveniles as adults. When it is put in this form, the argument requires proof that transferring juveniles to adult jurisdiction is an effective deterrent; either by deterring future crimes by these individuals (specific deterrence) or by deterring others beside the offender from committing crimes (general deterrence). Research efforts to date have not supplied compelling evidence that increasing the severity of sanctions deters more crime.

Singer and McDowall (1988) conducted a major study of the deterrent effect of New York's legislative waiver statute. Using an interrupted time series design with monthly arrest data to assess the effect of this statute on rates of homicide, assaults, rapes, or arsons. They concluded that while the law might have prevented robberies from increasing, it had no effect on homicides, assaults, rapes, or arsons committed by juveniles. Jensen and Metsger (1994) reached a similar conclusion in their investigation of the 1981 Idaho legislative waiver statute, which mandated the automatic waiver for youths aged fourteen to eighteen years who were accused of any one of five offenses: murder of any degree or attempted murder, robbery, forcible rape, mayhem, and assault or battery with the intent to commit any of the above specified crimes.

A stronger argument can be made that if juvenile offenders are transferred to adult jurisdiction, and if they are convicted, then by incapacitating these offenders through incarceration we reduce their opportunity to commit any crimes. It is likely that it is this feature that attracts many proponents of the policy of juvenile transfer, for while they may not be confident of the effectiveness of long prison sentences in deterring others or even the individual from future crimes, at least now he is "off the streets." For that time period anyway, people can enjoy their lives, feel a bit safer, confident that they will not be robbed or attacked by the incarcerated individual. Despite its popularity with lawmakers and DA's, there are a number of problems with such a view though. Studies conducted in the late 1970s and early 1980s found that the majority of juveniles sentenced in adult courts received probation or some other alternative to incarceration (Bishop et al., 1989). A similar study in an East Coast jurisdiction found no significant differences in the minimum and maximum terms imposed on similar juvenile and young adult defendants in juvenile and adult court (Fagan et al., 1987). A more recent study of waived youth in Texas prisons found that, when the actual time served was taken into consideration, these youths rarely served more lengthy sentences than are available in juvenile court, serving an average of only 27 percent of their original sentence (Fritisch et al., 1996).

This argument also assumes that treating juveniles as adults will decrease the overall amount of misery by removing them from society, but this will only be absolutely certain if they are never allowed to re-enter society. If they are to be released after 20 years, then one must consider what type of an individuals one will be releasing back into the community and consider what sort of influence twenty years of time will have in molding their character. One study found that, comparing overall crime rates for the cohorts, recidivism rates appeared to be higher for criminal court cases, their rearrests occurred more quickly, and their return to jail was more likely (Fagan, 1995).

Finally, perhaps the biggest problem is that while it is clear that transferring juvenile offenders to the adult system will increase their misery, it is not at all clear that incapacitation is the best way to reduce criminal activity among juvenile offenders. The present trend is founded on the assumption that there are only two options for dealing with juvenile offenders: to do nothing or to punish them as one would an adult. If this were true, then there would be a stronger argument for the policy of juvenile transfers; it would indeed be the best way to reduce crime. As we have pointed out, however, a more sophisticated analysis of the variety of programs provides evidence that there are consistent positive effects for particular intervention strategies. If this is correct, then there are not simply two options to be considered, rather there are three: to do nothing, to treat juveniles the same as adults, or to attempt to alter their behavior through these types of programs.

Since the last option does not rely on punishment (which is for the utilitarian a prima facie wrong) and achieves the same goal as deterrent or incapacitation policies (a reduction in crime), then it is clearly the preferable ethical choice and any other actions are wrong.

Whereas, the utilitarians hold that the assessment of the moral value of an action, either the criminal act or the punishing of that act, must be conducted by determining how much this action will increase or decrease the overall amount of happiness, the retributivist denies the relevancy of future outcomes as a meaningful indicator of the 
moral worth of an action and argues instead that all moral evaluation be based on the agent responsible for the act.

- Punishment is only morally justified if the punishment is connected to the agent actually responsible for the action.

- Responsibility is not an either/or condition but comes in degrees.

- The kind and degree of punishment inflicted upon the agent is related to the degree of the agent's responsibility.

As such, the punishment of juveniles as adults is only justifiable if they are responsible for their actions to the same degree that adults are. Delgado (1995) asserts that there are at least four questions that are relevant in assessing the degree of an agent's responsibility for a wrongful or criminal action: (1) Was the action was done voluntarily? (2) Did the agent understand the nature or consequences of the action? (3) Did the agent himself see his actions as wrongful or criminal? and (4) Was the agent acting from some compulsion, undue pressure, or otherwise unable to control his actions?

As before in the case of the utilitarian analysis, there is no substantial justification for the present trend of treating juveniles as adults. Policies governing a given population must be based on a realistic set of general assumptions made about that population. As a policy, it makes sense to presuppose that adults will know the consequences of their actions, be able to withstand peer pressure, and be able to control the impulsive aspects of their nature. Although there will be exceptions, we accept that these are reasonable psychological assumptions to make about the average adult. The onus is on the adult offender to show how circumstances or individual personality problems were such that they prevailed over the basic assumptions about their degree of responsibility and character. If we are to treat juveniles in the same manner as adults, then it must be the case that we would consider these reasonable presuppositions for them as well.

While some may wish it were otherwise, these are in fact, not necessarily reasonable assumptions to make about juveniles. As was pointed out, the research shows that juveniles are not as likely to understand the consequences of their actions, nor to have an advanced understanding of social mores, nor to be able to resist pressures. If one is to be morally justified in our treatment of juveniles, then whatever policies one construct must be predicated on realistic presupposition about the individuals involved. This would preclude the emerging policy and direct us to supporting policies that have been shown to be effective in developing and nurturing responsibility in juveniles.

\section{Vengeance on "other people's children"}

Evidence from developmental psychology, the consistent positive effects for particular intervention strategies, and the lack of ethical justification for the current practice of transferring youths to criminal court undermines the rationale for the current trend. In actuality, the rationale reflects the selective and continual manipulation of the alternative conceptions of young people as dependent and vulnerable or as autonomous and responsible to continue to justify policies that support and encourage cultural and racial discrimination.

Many observers have raised the issue for discussion that current calls for severe anticrime measures harbor racial subtexts (Wilson, 1992; Hacker, 1995). Feiler and Sheley (1999) examined the issue of public support for the harsher treatment of offenders through analysis of individuals' willingness to treat juvenile offenders as adults subject to criminal penalties. They found that even when the crime in question is seriously violent, citizens are less likely to desire the transfer of a younger juvenile. Though the race of the respondent played no role in the desire to transfer youth to adult court, the race of the offender clearly does. Whether Black or White, citizens are somewhat more likely to express a preference for transfer if the juvenile in question is Black. Feld (1998) calls this "The political demonization of young Black males as morally impoverished 'super-predators'..." Fear of violent juvenile offenders is almost always a fear of other people's children and has been throughout the twentieth century history of the United States (Zimring, 1998). The image of the violent juvenile offender, now and in the future, is that of a dark-skinned stranger. Yet, in 1997, in contrast to the proportions in the general population, 53 percent of juvenile arrests for violent crimes involved White youth and 44 percent involved Black youth (Snyder, 1998).

Discretionary decisions at various stages of the justice process amplify racial disparities as minority youths proceed through the system and result in more severe dispositions than for comparable White youths. Although minority youth constituted about 32 percent of the youth population in the country in 1995 , they represented 68 percent of the juvenile population in secure detention and 68 percent of those in secure institutional environments such as training schools (Sickmund et al., 1997). These figures reflect significant increases over 1983, when minority youth represented 53 percent of the detention population and 56 percent of the secure juvenile corrections population. 
Additional research has consistently substantiated that minority overrepresentation has not been limited to confinement in secure facilities; it also is significant at each of the major decision points in the juvenile justice system process (e.g., arrest, detention, prosecution, adjudication, transfer to adult court, and commitment to secure facilities).

After controlling for the present offense and prior records, a juvenile's race consistently exerts an independent effect on detention decisions (Pope \& Feyerherm, 1990). Between 1977 and 1982, the proportion of minority youths held in detention centers increased from 41 percent to 51 percent, a growth rate that did not reflect either racial demographics or arrest rate trends (Krisberg et al., 1986). Although juvenile courts detained about 20 percent of all referred youths, White juveniles experienced somewhat lower detention rates (18 percent) and Black (25 percent) and other racial minority (22 percent) juveniles experienced somewhat higher rates (Butts et al. 1996). A study of felony cases referred by police and detained by juvenile courts found that a youth's race affected both decisions, even after controlling for weapon use, victim injury, and socioeconomic and family structure (Wordes et al., 1994).

Cases involving White youths were less likely to be waived than cases involving Black youth and other minorities (Stahl, 1999). In 1996, 1.4 percent of formally processed cases involving Black juveniles were waived to criminal court, compared with 0.8 percent of cases involving White. In addition to a disproportion between minorities and White youths in terms of numbers, differential rates are also found in the type of offense. An analysis in four states that examined the effects of race on judicial waiver decisions found that

Blacks were more likely than Whites to have their cases waived for violent, property, and drug offenses. For violent offenses, the differential rates are fairly consistent across states, with Black juveniles having waiver rates from 1.8 times to 3.1 times higher than Whites. The differences varied more widely for drug offenses. Pennsylvania Black juveniles were more than twice as likely to have their cases waived than Whites... Arizona's waiver rates for Whites were twice those of California; while for Blacks, Arizona's rates were 55 times those of California (US General Accounting Office, 1995).

This differential rate based on the type of offense is confirmed by national data (Stahl, 1999). Throughout the period from 1987 to 1996 , cases involving White juveniles were most likely to be waived if the serious charge was a person offense. The use of waiver in cases involving Black youth changed considerably between 1987 and 1996. The use of transfer for Black youth charged with drug offenses increased substantially between 1985 and 1991 from 2.3 percent to 5.9 percent of formal cases. In 1992, waivers of drug cases declined for Black youth to 3.6 percent, but this was still higher than for White juveniles (1 percent). By 1966, waivers of drug cases for Black youth declined to 1.9 percent, but this still remains higher than for White youth ( 0.8 percent).

Prevalence studies to examine the likelihood of juveniles being incarcerated in a juvenile corrections facility before the age of eighteen were conducted in sixteen States (DeComo, 1993). These studies showed that African-American youth had the highest prevalence rates of all segments of the population in fifteen of the sixteen States. In two states, it was estimated that one in seven African-American males (compared with approximately one in 125 White males) would be incarcerated before the age of eighteen.

What is true in the early twentieth century is true today. Early juvenile court practitioners unabashedly

Classified delinquent children into three groups on the basis of social status, 'which best indicates the dispositions to be made.' Discharge or warning was most applicable to children whose homes and social influences were 'thoroughly good.' Probation was suitable for those whose home and social influences were 'ineffective.' Lastly, the 'mentally or morally defective' children of low social status required institutional or foster home placement. 'Probation is rarely a satisfactory disposition in such cases - and a discharge is worse.' The often explicit assumption that 'other people's children' - particularly those of the 'dangerous classes' were the true delinquents (Colomy \& Kretzmann, 1995).

Today, the juvenile justice system continues to provide legal authority for administrative discretion and continuity with earlier strategies to regulate "other people's children," especially those of the "dangerous classes." Bridges and Steen (1998) examined on how court officials' perceptions of offenders influence their classification, assessment, and final recommendations for punishment. They found that probation officers consistently portrayed Black youths differentially than White youths in their written court reports, more frequently attributing Blacks' delinquency to negative attitudinal or personality traits. Their depictions of White youths more frequently stressed the influence of the individual's social environment. These attributions shaped assessments of the threat of future crime and sentence recommendations, and become the mechanism by which race influences judgments of dangerousness and dispositions. Court officials judged Black youth as more dangerousness than White youths because they attribute crime by Blacks to negative personal- 
ities or their attitudinal traits. In so far as officials recommended severe sentences, they did so on the basis of these negative personalities that made Blacks "more dangerous."

\section{Conclusion}

The current concern with juvenile violence has produced a flood of legislative activity to increase the number of violent juveniles that qualify for transfer to criminal court. In 1966, thirty-five states automatically exclude cases from the juvenile court that meet specific age and offense criteria; eleven states allow prosecutors the discretion to file certain juvenile cases directly in criminal court. In all but four states (Massachusetts, Nebraska, New Mexico, and New York), a juvenile court judge is authorized to waive the juvenile court's original jurisdiction over cases that meet certain criteria and to refer them to criminal court for prosecution (Stahl, 1999).

To say that a system has problems is not, in and of itself, adequate justification to replace it with something else unless the something else is an improvement. There are juveniles who are irredeemable and therefore beyond the ability of any treatment or program to salvage. But there is hardly unanimity among juvenile justice professionals, community leaders, or politicians that getting tough is a sufficient response to delinquency behavior.

The current increasing rush to transfer youths to criminal court cannot be justified by knowledge from developmental psychology, evidence from the consistent positive effects for particular intervention strategies, ethical justification for punishment, or racism. Current practice is merely a continuation of earlier strategies that provided legal authority for administrative discretion and continuity to regulate "other people's children," and support cultural and racial discrimination.

Unfortunately, one of the problems in conducting an intelligent debate on this subject has been the high profile given in the media to especially horrific or grotesque crimes committed by such relatively rare individuals. This imbalance in turn drives policies that do not take into account precisely the fact that these are unique situations. Witness the recent announcement that a Texas legislator has introduced a bill to allow juveniles as young as eleven years old to be charged with capital crimes and face execution, as well as eliminate the minimum age at which a juvenile can be held accountable in the juvenile court system (Criminal Justice Newsletter, 1998).

To achieve an optimal balance between effective treatment, accountability, and community protection, the available evidence suggests that juvenile courts require access to a broad array of dispositional options. These extend from formal diversion to local accountability boards or social services, through inhome supervision and day treatment, to a variety of out-of-home placements providing different levels of security and types of treatment. The evidence also suggests that a certain degree of skill and experience is required to develop and run both institutional and community-based correctional programs that are effective in changing behaviors. There are no simple solutions or magic cures for the juvenile court to apply to problems of juvenile delinquency. The most effective systems and processes will be flexible and continuously experimental in their approach, provide a wide range of treatment and placement options, and be accountable for their results.

\section{References}

Bishop, D., Frazier, C., \& Henretta, J. (1989). Prosecutorial waiver: case study of questionable reform. Crime Delinquency 35, 179-201.

Bridges, G., \& Steen, S. (1998). Racial disparities in official assessments of juvenile offenders: attributional stereotypes as mediating mechanisms. Am Sociol Rev 63, 554-570.

Butts, J., Snyder, H., Finnegan, T., Aughenbaugh, A., \& Poole, R. (1996). Juvenile Court Statistics 1994. Washington, DC: Office of Juvenile Justice and Delinquency Prevention.

Colomy, P., \& Kretzmann, M. (1995). Projects and institution building: Judge Ben B. Lindsey and the juvenile court movement. Soc Probl 42, 191-205.

DeComo, R. (1993). Juveniles Taken into Custody Research Program: Estimating the Prevalence of Juvenile Custody by Race and Gender. San Francisco, CA: National Council on Crime and Delinquency.

Delgado, R. (1995). Rotten social background: should the criminal law recognize a defense of severe environmental deprivation? In: J. Murphy (Ed.), Punishment and Rehabilitation (pp. 249-273). Belmont, CA: Wadsworth.

Elkind, D. (1967). Egocentrism in adolescence. Child Dev $38,1025-1034$.

Fagan, J. (1995). Separating the men from the boys: the comparative advantage of juvenile versus criminal court sanctions on recidivism among adolescent felony offenders. In: J. Howell, B. Krisberg, J. D. Hawkins, \& J. Wilson (Eds.), A Sourcebook: Serious, Violent and Chronic Juvenile Offenders (pp. 238-260). Thousand Oaks, CA: Sage.

Fagan, J., Forst, M., \& Vivona, T. (1987). Racial determinants of the judicial transfer decision: prosecuting violent youth in criminal court. Crime Delinquency 33, 259-296.

Feiler, S., \& Sheley, J. (1999). Legal and racial elements of public willingness to transfer juvenile offenders to adult court. J Crim Justice 27, 55-64. 
Feld, B. (1998). Bad Kids: Race and the Transformation of the Juvenile Court. New York: Oxford Univ. Press.

Fritisch, E., Caeti, T., \& Hemmens, B. (1996). Spare the needle but not the punishment: the incarceration of waived youth in texas prisons. Crime Delinquency 42, $593-609$.

Gallagher, C. (1999). Juvenile Offenders in Residential Placement, 1997. Washington, DC: Office of Juvenile Justice and Delinquency Prevention.

Garrett, C. (1985). Effects of residential treatment on adjudicated delinquents: a meta analysis. J Res Crime Delinquency 22, 287-308.

Hacker, A. (1995). Two Nations. New York: Ballantine Books.

Hofstader, R. (1955). The Age of Reform. New York: Knopf.

Jensen, E., \& Metsger, K. (1994). A test of the deterrent effect of legislative waiver on violent juvenile crime. Crime Delinquency 40, 96-104.

Kant, I. (1979). The Metaphysics of Morals. (Mary Gregor, Trans., 1991). New York: Cambridge Univ. Press.

Kietzman, M., Spring, B., \& Zubin, J. (1985). Perception, cognition, information processing. In: H. Kaplan \& B. Sadock (Eds.), Comprehensive Textbook of Psychiatry (pp. 157-163). Baltimore: Williams and Wilkins.

Krisberg, B., Schwartz, I., Fishman, G., Eisikovits, Z., \& Guttman, E. (1986). The Incarceration of Minority Youth. Minneapolis, MN: University of Minnesota.

Lipsey, M. (1992). Juvenile delinquency treatment: a meta-analytic inquiry into the variability of effects. In: T. Cook, H. Cooper, D. Cordray, H. Hartmann, I. Hedges, R. Light, T. Louis, \& F. Mosteller (Eds.), Meta Analysis for Explanation: A Casebook (pp. 83127). New York: Russell Sage Foundation.

Lipsey, M., \& Wilson, D. (1998). Effective intervention for serious juvenile offenders: a synthesis of research. In: R. Farrington \& D. Farrington (Eds.), Serious and Violent Juvenile Offenders: Risk factors and Successful Interventions (pp. 313-345). Thousand Oaks, CA: Sage.

Martinson, R. (1974). What works? Questions and answers about prison reform. The Public Interest 10, 22-54.

Mill, J. (1983). Utilitarianism. New York: Bobbs Merrill.

Murphy, J. (1995). Punishment and Rehabilitation. Belmont, CA: Wadsworth Publishing.

Palmer, T. (1992). The Re-Emergence of Correctional Interventions. Thousand Oaks, CA: Sage.
Pope, C., \& Feyerherm, W. (1990). Minority status and juvenile justice processing: an assessment of the research literature. Crim Justice Abstr 22, 527-542.

Rogers, D. (1981). Adolescents and Youth. Englewood Cliffs, NJ: Prentice-Hall.

Rothman, D. (1980). Conscience and Convenience: The Asylum and Its Alternatives in Progressive America. Boston: Little Brown.

Ryerson, E. (1977). The Best-Laid Plans: America's Juvenile Court Experiment. New York: Hill and Wang.

Schlossman, S. (1977). Love and the American Delinquent: The Theory and Practice of "Progressive" Juvenile Justice. Chicago: University of Chicago Press.

Scott, E., \& Grisso, T. (1997). The evolution of adolescence: a developmental perspective on juvenile justice reform. J Crim Law Criminol 88, 137-190.

Sickmund, M., Snyder, H., \& Poe-Yamagata, E. (1997). Juvenile Offenders and Victims: 1997 Update on Violence. Washington, DC: Office of Juvenile Justice and Delinquency Prevention.

Singer, S., \& McDowall, D. (1988). Criminalizing delinquency: the deterrent effects of the New York juvenile offender law. Law Soc 22, 521-535.

Snyder, H. (1998). Juvenile Arrests 1997. Washington, DC: Office of Juvenile Justice and Delinquency Prevention.

Stahl, A. (1999). Delinquency Cases Waived to Criminal Court, 1987-1996. Washington, DC: Office of Juvenile Justice and Delinquency Prevention.

Steinberg, L., \& Cauffman, E. (1996). Maturity of judgment in adolescence: psychosocial factors in adolescent decision-making. Law Hum Behav 20, 249-268.

Ten, C. (1987). Crime, Guilt and Punishment. New York: Oxford Univ. Press.

US General Accounting Office (1995). Juvenile Justice: Juveniles Processed In Criminal Court And Case Dispositions. Washington, DC.

Wilson, J. (1992). Crime, race, and values. Society 30, 90-93.

Wordes, M., Bynum, T., \& Corley, C. (1994). Locking up youth: the impact of race on detention decisions. $J$ Res Crime Delinquency 31, 149-165.

Zimring, F. (1998). American Youth Violence. New York: Oxford Univ. Press. 